ZOOLOGIA 27 (5): 820-828, October, 2010

doi: $10.1590 /$ S1984-46702010000500019

\title{
First report of Temnocephala rochensis (Platyhelminthes: Temnocephalida) from Pomacea canaliculata (Mollusca: Ampullariidae) outside Uruguay - description update based on specimens from the state of Rio Grande do Sul, Brazil
}

\author{
Samantha A. Seixas; José F. R. Amato \& Suzana B. Amato
}

Departamento de Zoologia, Instituto de Biociências, Universidade Federal do Rio Grande do Sul. Caixa Postal 15014, 91501-970 Porto Alegre, RS, Brazil.

Correponding author. E-mail: samantha_bio@yahoo.com.br

\begin{abstract}
Temnocephala rochensis Ponce de Léon, 1979, was the second of four species of Temnocephala Blanchard, 1849 to be described as ectosymbiont of ampullariid apple snails, Pomacea canaliculata (Lamarck, 1822). There have been no records of this Uruguayan species after its initial description. As part of the present study, 111 specimens of $P$. canaliculata were collected between 2003 and 2009. Temnocephalans found in the pallial cavity were identified as $T$. rochensis, occurring in single infestations, or concurrently with Temnocephala haswelli Ponce de Léon, 1989. Specimens of $T$. rochensis showed a conspicuous red eye pigment which faded after ethanol fixation. Important taxonomic characters of the reproductive system were evidenced by several techniques, and documented photographically for the first time for this species: 1) the typical curved cirrus of the species showing very short and stout spines; 2 ) the vagina with the proximal portion dilated, forming a "vesicula intermedia"; and 3) the distal portion very muscular, as well as the large and symmetrical vaginal sphincter were documented in detail with Nomarski's DIC microscopy. Eggs were observed in the suture, in the spire, and in the umbilicus of the shell; they had a short peduncle or were sessile, always with short and curved, sometimes straight apical filaments. The rounded shape of the dorsolateral 'excretory' syncytial epidermal plates had central nephridiopores. This is the first record of this species outside of Uruguay and in the State of Rio Grande do Sul, Brazil. Even with extended sampling efforts in the eastern region of Rio Grande do Sul, T. rochensis has not been found, showing a geographical distribution restricted to the southern region, close to its type locality of Laguna Negra, Uruguay.
\end{abstract}

KEY WORDS. Ectocommensals; mollusks; Neotropical Region; South America; taxonomy.

Temnocephala Blanchard, 1849, together with Didymorchis Haswell, 1900, are the only autochthonous temnocephalans in the Neotropical Region. Twenty-five species of Temnocephala have been described to date (Damborenea \& Cannon 2001, Amato et al. 2003, 2006, 2007, Амato \& Aмato 2005, Volonterio 2007, Damborenea \& BRUSA 2008). Four species have been described as ectosymbionts of ampullariid apple snails (Haswell 1893, PONCE de León 1979, 1989, Damborenea \& Brusa 2008). Temnocephala iheringi Haswell, 1893 was recently redescribed by SEIXAS et al. (2010a). Temnocephala rochensis Ponce de León, 1979 was the second species described as ectosymbiont of Pomacea canaliculata (Lamarck, 1822), and, so far, it had been recorded only once, from Uruguay (PonCE DE León 1979). Temnocephala haswelli Ponce de León, 1989 was recorded for the first time outside of Uruguay by SeIXAS et al. (2010b), who included a description update based on specimens from Rio Grande do
Sul, Brazil. The most recently described species from ampullariid snails was Temnocephala lamothei Damborenea \& Brusa, 2008 as ectosymbiont of Pomella megastoma (Sowerby, 1825) from Argentina (Damborenea \& BRUSA 2008).

The present work records, for the first time, T. rochensis outside of Uruguay. A complete study (showing several specific characters) of this species had not yet been published. Thus, we present a complete characterization following the methodology of Амaто et al. (2007) and Seixas et al. (2010a).

\section{MATERIAL AND METHODS}

One-hundred-and-eleven specimens of $P$. canaliculata were collected between 2003 and 2009, using dip nets and/or large sand sieves, and transported live to the Laboratório de Helmintologia, Universidade Federal do Rio Grande do Sul 
(UFRGS). Live temnocephalans were obtained from hosts collected in the following localities: Fazenda Sossego, $30 \mathrm{~km}$ West of Santa Vitória do Palmar ( $\left.33^{\circ} 16^{\prime} 13^{\prime \prime} \mathrm{S}, 053^{\circ} 26^{\prime} 28^{\prime \prime} \mathrm{W}\right)$, municipality of Santa Vitória do Palmar; second order creek joining Arroio do Juncal, Fazenda da Invernada $\left(32^{\circ} 27^{\prime} 08,8^{\prime \prime}\right.$, $\left.053^{\circ} 15^{\prime} 44,6^{\prime \prime} \mathrm{W}\right)$; pond at Fazenda da Invernada $\left(32^{\circ} 27^{\prime} 41^{\prime \prime} \mathrm{S}\right.$, $\left.053^{\circ} 15^{\prime} 14,2^{\prime \prime} \mathrm{W}\right)$; side way pond along the Interstate Road BR $116(\mathrm{~km} \mathrm{12})\left(32^{\circ} 28^{\prime} 21^{\prime \prime} \mathrm{S}, 053^{\circ} 17^{\prime} 20,5^{\prime \prime} \mathrm{W}\right)$; side way ditch on the road to Fazenda São João $\left(32^{\circ} 35^{\prime} 29,7^{\prime \prime}\right.$ S, 05314'04,5”W), municipality of Jaguarão; and a wet area along the secondary road to São Lourenço do Sul $\left(31^{\circ} 20^{\prime} 21,4^{\prime \prime}\right.$ S, $\left.052^{\circ} 03^{\prime} 10^{\prime \prime} \mathrm{W}\right)$, municipality of São Lourenço do Sul. All the above municipalities are in the state of Rio Grande do Sul, Brazil and belong to the same Coastal River Basin, Mirim-São Gonçalo Sub-water Basin and are included in the Atlantic Rain Forest (Brazilian Atlantic Forest Biome).

Some of the helminths taken from live hosts were studied and photomicrographed alive or fixed and stained according to SEIXAs et al. (2010a) for internal morphometry. To preserve the red pigmentation of the eyespots and the shape of the body, and for the purpose of scanning electron microscopy studies (SEM), some specimens were flooded in hot phosphate buffered 10\% formalin (HF) (Амато et al. 2005, 2006). The description of the morphology of the dorsolateral 'excretory' syncytial epidermal plates (DLSPs) and the distribution of rhabditogenic and disc glands followed Амато et al. (2007). Photomacrographs of hosts showing egg distribution and live helminth pigmentation were taken with a Zeiss Stemi SV-6 stereomicroscope (Figs 1-4 and 6). Photomicrographs were taken with a Zeiss Axiolab microscope with phase contrast (or just the phase contrast condenser), a Leica DMR Hc microscope with Nomarski's differential interference contrast (DIC) prisms, and a Jeol (JSM-6060) SEM. Drawings were made with a drawing tube on a Nikon E-200 microscope. The photographic images and scanned line drawings were prepared using Adobe's Photoshop CS2 ${ }^{\circledR}$ and CorelDraw X $4^{\circledR}$, respectively. Measurements are in micrometers $(\mu \mathrm{m})$ unless otherwise indicated; ranges are followed by the arithmetic mean, the number of specimens measured for a given character (when different than 15), and the standard deviation values (between parentheses). A number of internal organs were no longer measured and the terminology used followed SeIXAs et al. (2010a). Voucher specimens fixed in AFA or silver nitrate (SN), as well as slides containing individual cirri in Faure's mounting medium (F) were deposited in the 'Coleção Helmintológica do Instituto Oswaldo Cruz' (CHIOC), Rio de Janeiro, RJ, Brazil. Other voucher specimens stained in Delafield's hematoxylin were deposited in the 'Colección de la Sección Helmintológica, División Zoología Invertebrados, Museo de La Plata' (MLP), La Plata, Buenos Aires, Argentina. The host specimens and remaining temnocephalans are in the host and helminth collections of the 'UFRGS Coleção Helmintológica do Laboratório de Helmintologia', Porto Alegre, RS, Brazil.

\section{TAXONOMY}

\section{Temnocephala rochensis Ponce de León, 1979}

Figs 4-27

Description. Based on 58 specimens collected: 46 whole mounted adult specimens; 12 juveniles; 2 specimens mounted on stubs for SEM; 5 dissected cirri mounted in F; 2 mounted specimens fixed in $\mathrm{SN} ; 15$ specimens fixed in AFA under slight cover slip pressure measured.

External characteristics. Body (without tentacles) (Fig. 7) 2.23-3.45 mm (2.80 mm, 361) long, 1.11-2.53 mm (1.54 mm, $352)$ wide; adhesive disk ventral, subterminal, partially covered by body (Fig. 7) 573-829.5 $(689,89)$ long, 513-1.09 mm $(799,130)$ wide; disc peduncle 99-375 $(226,73)$ long, 118.5$474(349,84)$ wide; relationship between ratio of maximum cirrus length/adhesive disk diameter 3.51: 1. Eyespots with red pigmentation present (observations made on live specimens) (Fig. 6). Two dorsolateral, epidermal 'excretory' syncytial plates, large and rounded (Figs 15 and 16), left plate 480-700 (500, n = $2,28)$ long, $550-750(650, \mathrm{n}=2,141)$ wide; right plate $430-700$ (565, $\mathrm{n}=2$, 191) long, 540-560 (550, $\mathrm{n}=2,14)$ wide; ratio of length of DLSPs/total body length, without tentacles, 4.75: 1. Nephridiopore central (Figs 15 and 16).

Glands. Rhabditogen glands forming bunches (average 27 cells), in lateral fields of body (Figs 8 and 10), 40-85 $(57,12)$ in diameter, ducts conspicuous (Fig. 8). Two groups of five Haswell glands (Fig. 12), showing little affinity with hematoxylin, in front of the brain transverse band (Fig. 12), diameter of largest cell 55-117.5 $(78,17)$. Disc glands between adhesive disc and genital complex, forming two, lateral bunches extending from posterior testes to margin of adhesive disc (Fig. 11), including two pairs, of large, round, more central cells (paranephrocytes?), 50-92.5 $(63,10)$ in diameter (Fig. 11).

Reproductive system. Female: vitellarium arborescent, completely covering intestine dorsally (Fig. 12), ventral region partially covered in lateral margins; vagina long, narrow, with proximal portion dilated, forming a "vesicula intermedia" and the distal portion muscular (Figs 13 and 23-24), 72.5-195 (128, 28) long, 52.5-92.5 $(75,11)$ maximum width; sphincter large, symmetrical (Figs 23 and 24) 67.5-100 $(88,10)$ in diameter; diameter of anterior portion $25-42.5(35,5)$, diameter of posterior portion 27.5-47.5 (38, 5); vesicula resorbens thick-walled, usually full of sperm (Fig. 13), 200-380 (281, 57) long, 170-350 $(261,52)$ wide; wall thickness 7.5-17.5 $(12,3)$. Eggs sessile or pedunculate (Figs 4 and 5), fixed in umbilicus, suture, and in spire, sometimes in larger number in the body whorl (Figs 2 and 3), 400-520 (477, n $=9$, 38) long, 220-290 $(247, \mathrm{n}=9,22)$ wide; filament long, apical (Fig. 5) 70-200 (131, $\mathrm{n}=8$, 49) long; peduncle, when present, 17.5-77.5 (50, $\mathrm{n}=7,20)$ long; opercular plates observed.

Male: Seminal vesicle short, wide, thick-walled (Figs 14 and 25-26) 137.5-337.5 $(251,57)$ long, 90-150 $(113,15)$ wide; wall thickness 12.5-27.5 $(21,5)$; prostatic bulb with muscular wall (Figs 14, 25, and 27), 152.5-362.5 (240, 48) long, 100-225 (145, 

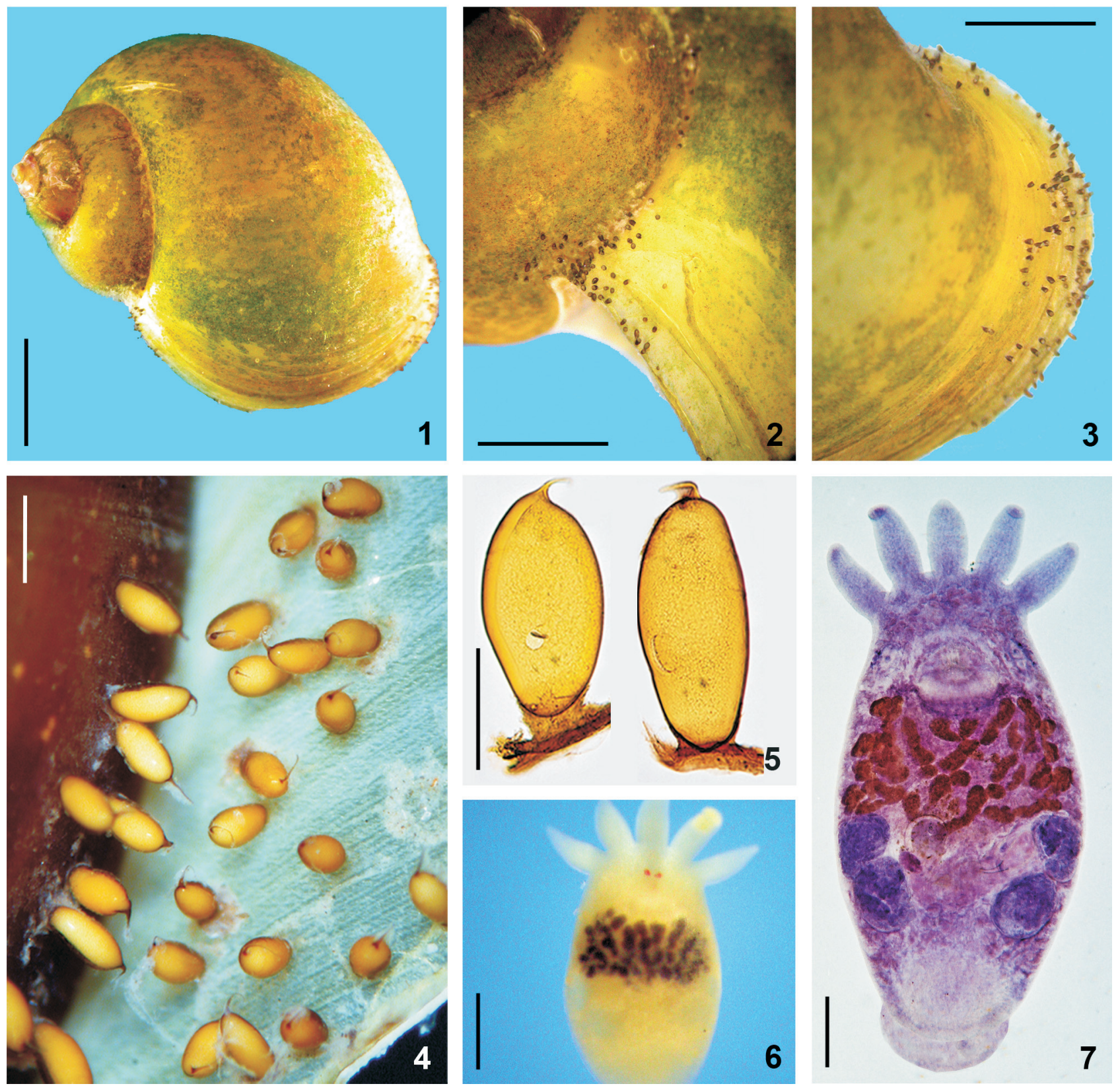

Figures 1-3. Pomacea canaliculata, showing areas of egg deposition; (4-7) Temnocephala rochensis: (4) eggs on the host shell; (5) eggs cleared and mounted in Canada balsam; (6) specimen fixed in formalin showing the red eye pigmentation; (7) adult specimen, pressed between slide and cover slip, stained in Delafield's hematoxylin. Scale bars: $1=10 \mathrm{~mm}, 2-3=5 \mathrm{~mm}, 4-7=500 \mu \mathrm{m}$.

$35)$ wide; wall thickness 12.5 -27.5 (16, 4); prostatic vesicle present (Figs 14 and 27). Cirrus long, slightly curved when observed from the side (Figs 17 and 18) 237.5-250 $(243, \mathrm{n}=5,6)$ long, shaft 197-212.5 (204, $\mathrm{n}=5,6)$ long, shaft base 70-100 $(84, \mathrm{n}=5,12)$ wide; introvert 35-42.5 $(39, \mathrm{n}=5,3)$ long, 15-27.5 $(20, \mathrm{n}=5,5)$ wide at base; maximum introvert width at level of swelling, 22.5-
$30(25.5, \mathrm{n}=5,3)$. Introvert's swelling with approximately 22 longitudinal rows of very short and stout spines, approximately 6 spines per row (Figs 19-22). Ratio between total body length, without tentacles/total length of cirrus 11.5: 1; ratio between total length of cirrus/maximum width of shaft's base 2.9: 1 ; ratio between total length of cirrus/total length of introvert 6.2: 1 . 

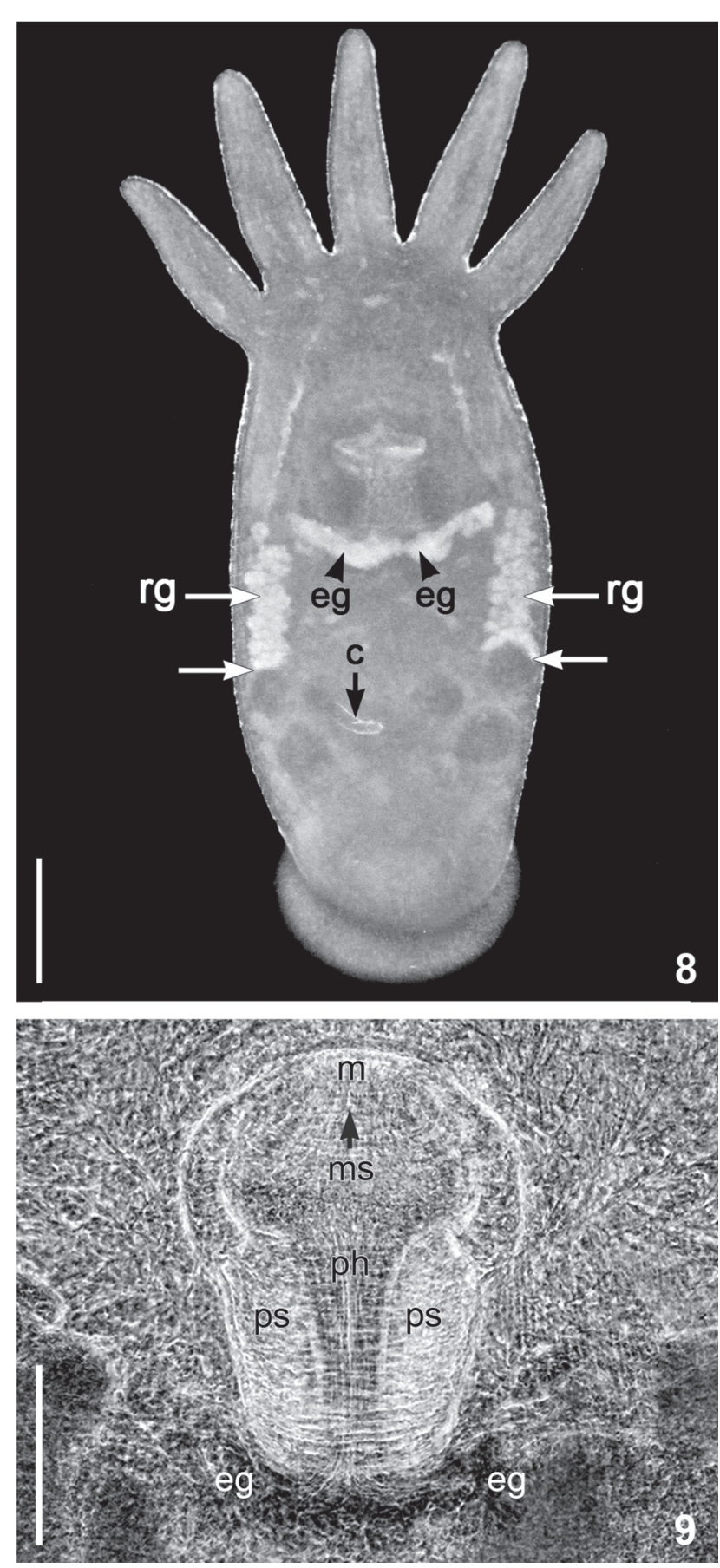

Figures 8-9. Temnocephala rochensis: (8) juvenile, ventral view, showing rhabditogen glands (rg), extending along sides of intestinal sac, and its ducts entering tentacles, esophageal glands (eg), the limit between the anterior rhabditogen glands and the posterior disc glands (white arrows), and cirrus (c); (9) mouth (m), mouth sphincter (ms), pharynx (ph), pharyngeal sphincter (ps), esophageal glands (eg). Scale bars: $250 \mu \mathrm{m}$.

\section{Taxonomic summary}

Type host and type locality. Pomacea canaliculata (Lamarck, 1822) (Gastropoda: Caenogastropoda: Ampullariidae), Laguna Negra, Rocha, Uruguay (Ponce de León 1979).

Other localities (present work). BRAZIL, Rio Grande do Sul: Fazenda Sossego and Fazenda dos Afogados, municipality of Santa Vitória do Palmar; Fazenda da Invernada, Rodovia BR 116 (km 12) and Fazenda São João, municipality of Jaguarão; inundated area along a secondary dirt road to São Lourenço do Sul, municipality of São Lourenço do Sul.

Site of infestation. Adults and juveniles in mantle cavity, eggs in umbilicus, suture, and spire, sometimes in larger numbers in the body whorl of the host shell; never present on operculum.

Overall prevalence. $74.8 \%$

Helminth specimens deposited. CHIOC 37250a-c, 37251voucher specimens fixed in AFA, stained in Delafield's hematoxylin; CHIOC 37247 a - voucher specimens (juvenile) fixed in AFA, stained in Delafield's hematoxylin; CHIOC 37250d, 37247bc - voucher specimens fixed in AFA, stained in aceto-carmine/ fast green; CHIOC $37250 \mathrm{e}-\mathrm{f}$ - cirri from voucher specimens, in F; CHIOC 37248 - unhatched eggs. MLP 5927-5932 - voucher specimens fixed in AFA and stained in Delafield's hematoxylin.

Other helminth specimens examined. Temnocephala rochensis Ponce de Léon, from Pomacea canaliculata, of Laguna Negra, Departamento de Rocha, Uruguay, Enero 1979. Paratype $\mathrm{N}^{\mathrm{o}} 22$.

Remarks. The red pigment of the eyes of $T$. rochensis, when compared with that of $T$. haswelli, is not very intense and disappears even when specimens are kept in 10\% phosphate buffered formalin. The vagina is peculiar, showing two distinct parts: it is dilated immediately after the seminal receptacles, presenting a "vesicula intermedia" and has strong muscular walls at the distal region. This is the most characteristic aspect of the female reproductive system (Figs 13 and 23). The vaginal sphincter is symmetrical with only minor differences between the diameters of the anterior and posterior portions. As a result, it cannot be classified as asymmetrical (average diameter of anterior portion $34.8 \mu \mathrm{m}$ and posterior portion $37.8 \mu \mathrm{m}$ ). The testes are also characteristic of the species. They are round, large, and together represent $1 / 3$ of the total body length without the tentacles (Figs 7 and 12). The seminal vesicle, although small, has a thick and muscular wall (Fig. 26). The cirrus is slightly curved, a feature that can be best observed in lateral view (Fig. 17). In ventral and dorsal views, it appears straight (Fig. 18).

\section{DISCUSSION}

Temnocephala rochensis was the second species described as ectosymbiont of P. canaliculata. PonCE de León (1979) described the species based on 30 specimens from two hosts collected at Laguna Negra, Departamento de Rocha, Uruguay, in January, 1978. According to the author, T. rochensis had never been found 

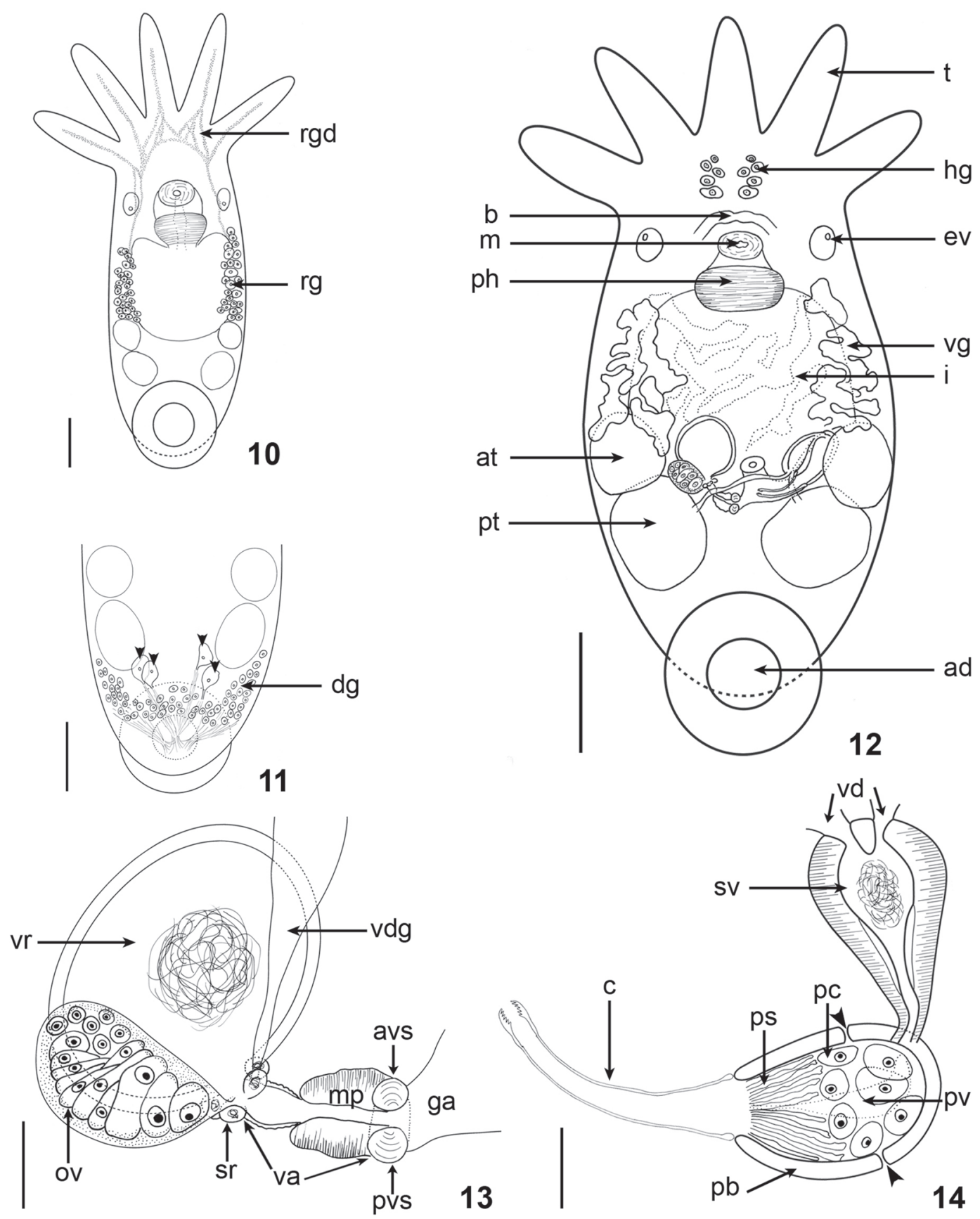

Figures 10-14. Temnocephala rochensis: (10) incomplete diagram of a juvenile specimen, rhabditogen gland ducts entering the tentacles (rgd), rhabditogen glands (rg); (11) juvenile, posterior region showing disk glands (dg) and the two pairs of large disk glands (paranephrocytes?) - black head arrows; (12) incomplete diagram of adult specimen fixed with cold AFA and slight cover slip pressure showing tentacles (t), Haswell glands (hg), brain transverse band (b), mouth (m), pharynx (ph), excretory vesicles (ev), vitellaria (vg), intestinal sac (i), anterior testes (at), posterior testes (pt), adhesive disk (ad); (13) female reproductive complex, showing vesicula resorbens (vr), ovary (ov), seminal receptacles (sr), vagina (va), distal vagina with muscular portion (mp), anterior (avs) and posterior (pvs) portions of the vaginal sphincter, genital atrium (ga), vitelline gland duct (vgd); (14) male reproductive complex: cirrus (c), vasa deferentia $(\mathrm{vd})$, seminal vesicle (sv), prostatic bulb (pb), prostatic vesicle (pv), prostatic cells $(\mathrm{pc})$, prostatic secretion (ps), and space in the wall of the prostatic bulb (head arrow). Scale bars: 10-11 $=200 \mu \mathrm{m}, 12=500 \mu \mathrm{m}, 13=100 \mu \mathrm{m}, 14=50 \mu \mathrm{m}$. 


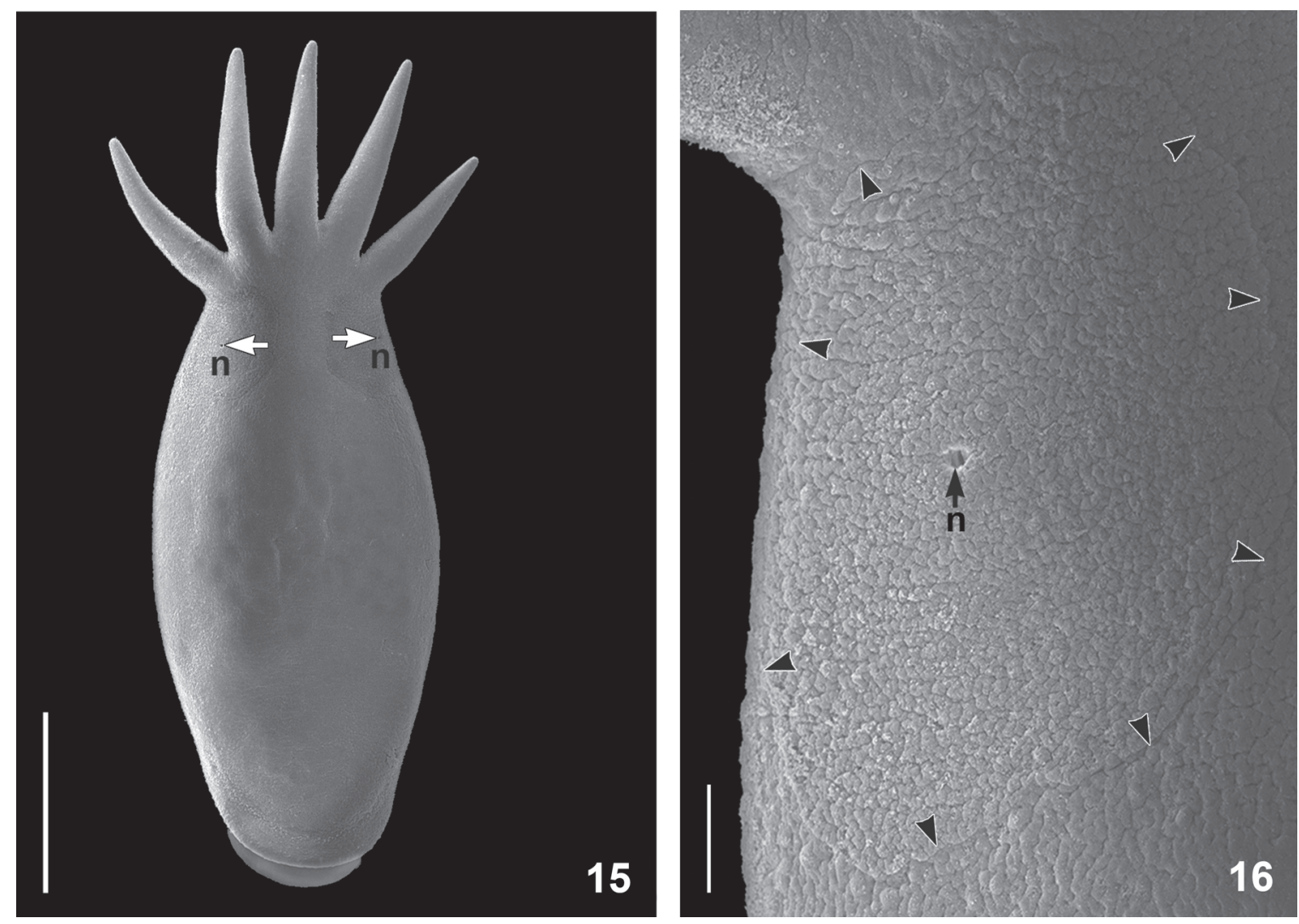

Figures 15-16. Temnocephala rochensis (SEM): (15) adult, dorsal view, showing dorsolateral 'excretory' syncytial plates and nephridiopore (n); (16) higher magnification of the right syncytial plate, showing the central nephridiopore ( $n$ ), and the limits of the plate (head arrows), Scale bars: $15=500 \mu \mathrm{m}, 16=50 \mu \mathrm{m}$.

again (pers. comm.). Damborenea \& CANnon (2001), when revising the Neotropical species, studied the specimens deposited in the author's collection. A single paratype, listed as other specimen studied, was a gift to one of us (JFA) from Ponce de León. We used this specimen for the observation of the cirrus. According to Ponce de León (1979) the species is small, contrasting with the representative specimens studied in the present work. The average size of the body (excluding tentacles) of specimens collected in Rio Grande do Sul is $2.8 \mathrm{~mm}$, differing from the average body length of $1.42 \mathrm{~mm}$ of the Uruguayan specimens. The cirrus is also longer in specimens from RS (243 $\mu \mathrm{m})$ than in specimens from Uruguay $(186 \mu \mathrm{m})$. It is possible that these differences are due to the fact that the author seems to have based his description on juvenile specimens, as portrayed in his illustrations. The peculiar female organs of $T$. rochensis seem to have induced the author to describe the vesicula resorbens as being "double", prompting him to call it "vesicula accesoria". In the present paper, a more careful observation allowed us to see that the "vesicula accesoria" of Ponce de León corresponds to a widening of the proximal vagina, which forms a vesicle previously seen in other species (Temnocephala kingsleyae Damborenea, 1994 and Temnocephala lutzi Monticelli, 1913). Damborenea (1994) and Amato et al. (2005) called it "vesicula intermedia". According to DAMBORENEA (1994), this vesicle substitutes the seminal receptacles in the two species just mentioned, but not in $T$. rochensis. The latter has the regular four seminal receptacles. The vagina in $T$. rochensis shows two distinct portions: the "vesicula intermedia" and a very muscular, distal portion adjacent to the sphincter, which is large and symmetrical. Other particular characters of T. rochensis are the large and rounded testes, and the very thick seminal vesicle, measuring up to $27.5 \mu \mathrm{m}$ (the seminal vesicle is usually not very muscular in other species). Although there is a series of differences when the specimens from Rio Grande do Sul are compared with the specimens previously described, a number of other characters agree with the original description by PONCE DE León (1979), particularly in regards to the morphology of the cirrus, the character with the highest taxonomical value, plus the distribution of the rhabditogen glands and the peculiarities of the female reproductive system. 

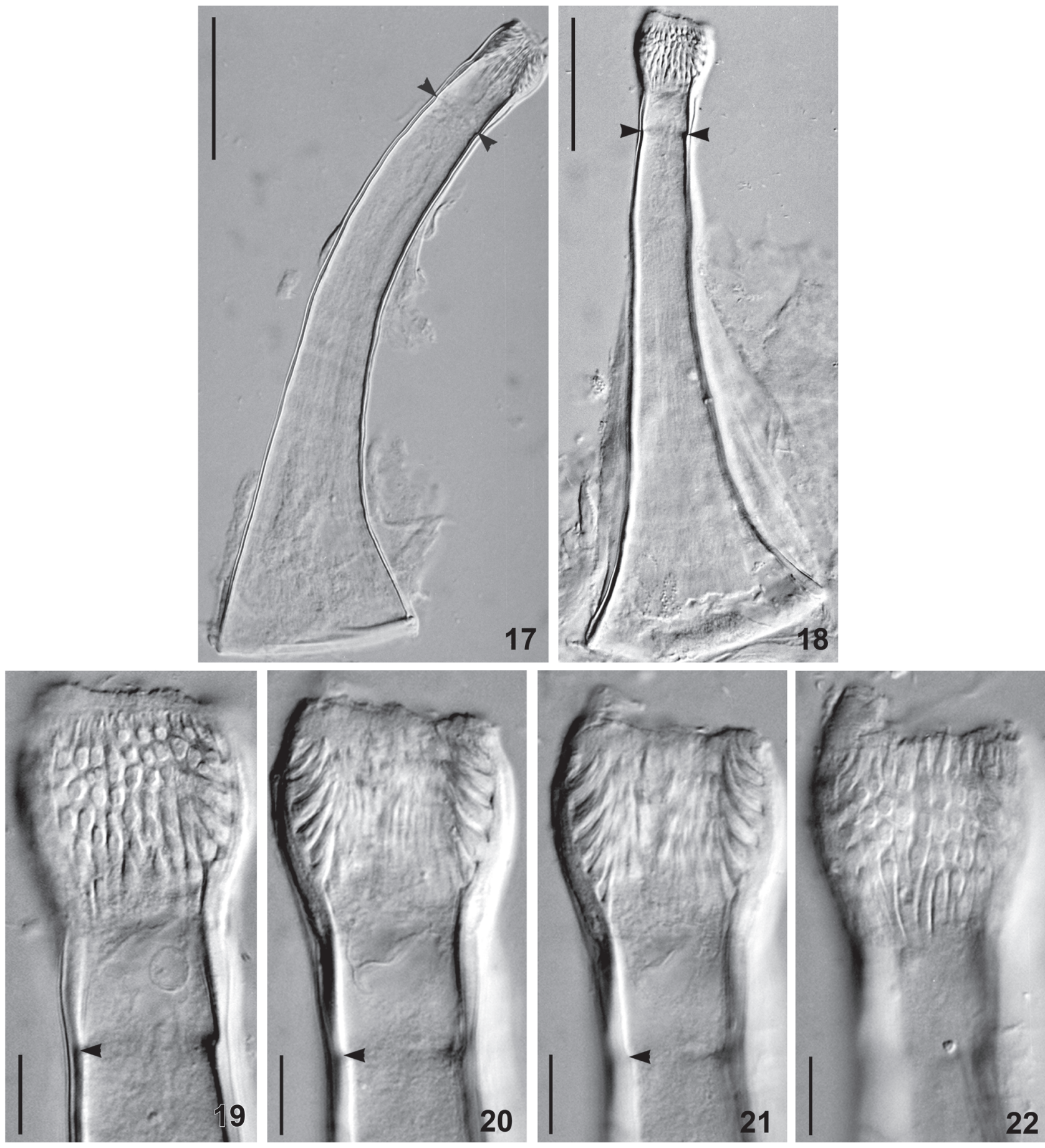

Figures 17-22. Temnocephala rochensis, photomicrographies of cirri, seen with Nomarski's DIC microscopy: (17) entire cirrus (lateral view), showing the evident curvature and the proximal limit of introvert (head arrows); (18) entire cirrus (dorsal or ventral view), proximal limit of introvert (head arrows); (19-22) photomicrographies selected from a series showing the introvert seen in different focusing planes, from the top of the internal surface to mid-section, proximal limit of introvert (head arrow). Scale bars: $17-18=50 \mu m$, $19-22=10 \mu \mathrm{m}$. 

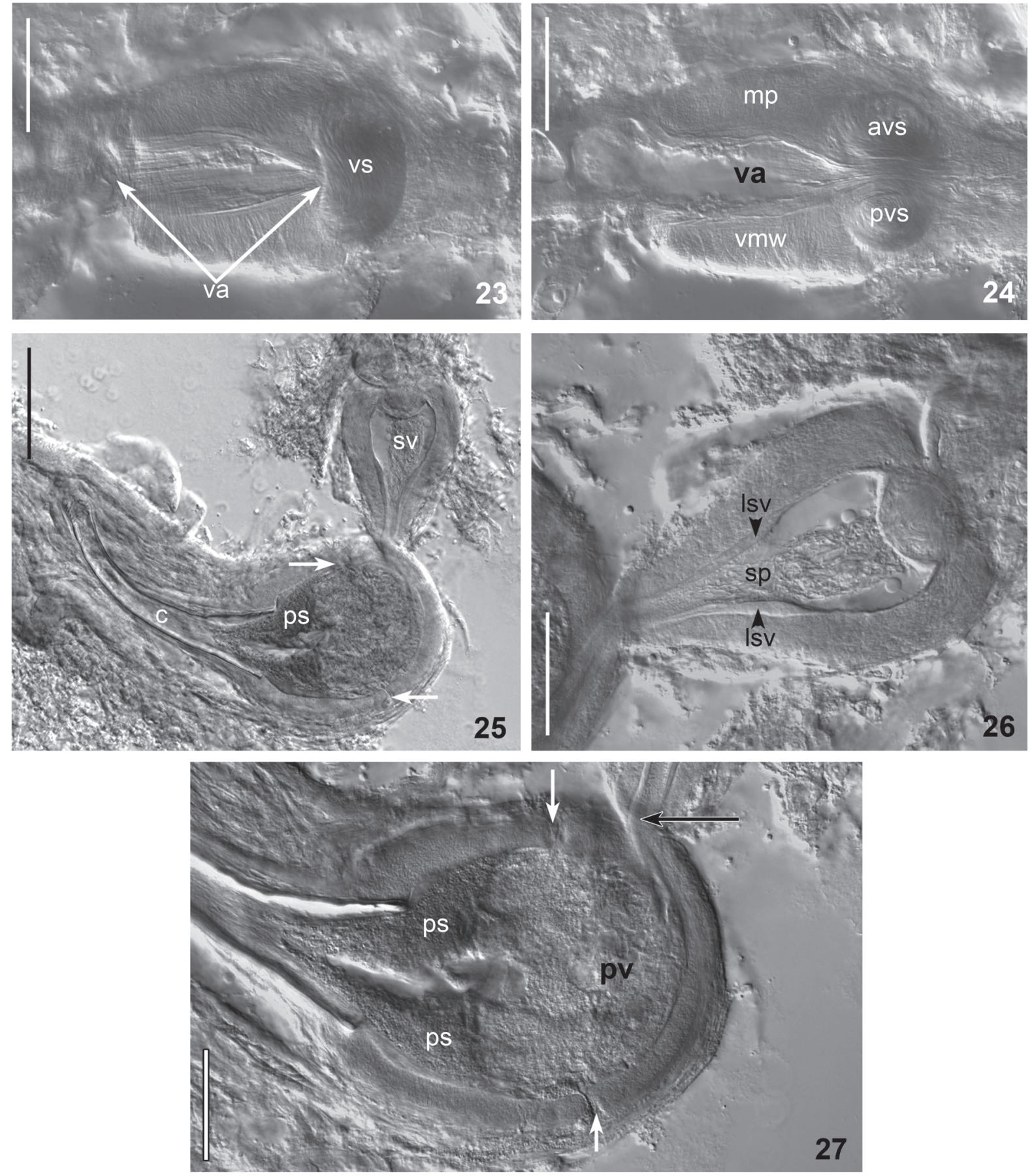

Figures 23-27. Temnocephala rochensis, selected characters of the reproductive system, seen with Nomarski's DIC microscopy: (23-24) partial female reproductive complex: (23) vagina (va), and the circular vaginal sphincter (vs); (24) distal vagina (va) with muscular portion ( $\mathrm{mp}$ ), vaginal muscular wall (vmw), anterior (avs) and posterior (pvs) portions of the circular vaginal sphincter; (25-27) partial male reproductive complex: (25) seminal vesicle (sv), prostatic secretion (ps), cirrus (c), and space in the wall of the prostatic bulb (arrows); (26) seminal vesicle showing the spermatozoids (sp) and lining of seminal vesicle (lsv); (27) prostatic bulb with space in the wall (white arrows), seminal vesicle entering prostatic bulb (black arrow), prostatic vesicle ( $p v)$, and prostatic secretion (ps). Scale bars $23-24,26-27=50 \mu \mathrm{m}, 25=100 \mu \mathrm{m}$. 
Despite extended sampling efforts in the eastern region of Rio Grande do Sul (collections of $P$. canaliculata referred in SEIXAS et al. 2010a and 2010b for the study about T. iheringi and T. haswelli, respectively), T. rochensis was found to be restricted to the southern region of the State, close to Laguna Negra, Uruguay.

\section{ACKNOWLEDGEMENTS}

To Jorge Ernesto de A. Mariath and Rinaldo P. dos Santos, Laboratório de Anatomia Vegetal (LaVEG), Instituto de Biociências, UFRGS, for the permission to use of the Leica DMR Hc microscope to make the DIC photomicrographs; to Centro de Microscopia Eletrônica (CME), UFRGS; to Maria C. Damborenea, Curator, Colección Helmintologica Museo de La Plata (MLP), División Zoología Invertebrados for receiving Brazilian voucher specimens of $T$. rochensis, collected and prepared by us, for deposit; to Rodrigo Ponce de León for kindly donating to our Helminthological Collection a paratype of T. rochensis; to Philip J. Scholl for the help in the field and for kindly reviewing the English version of the manuscript; to Fábio Villela for the specimens collected in Jaguarão; and to Lauren B. Pordany for her help in the field and the laboratory.

\section{LITERATURE CITED}

Amato, J.F.R.; S.B. Amato \& L.C.C. Daudt. 2003. New species of Temnocephala Blanchard (Platyhelminthes, Temnocephalida) ectosymbiont on Aegla serrana Buckup \& Rossi (Crustacea, Anomura) from southern Brazil. Revista Brasileira de Zoologia 20 (3): 493-500.

Амato, J.F.R. \& S.B. Амато. 2005. New species of Temnocephala Blanchard (Platyhelminthes, Temnocephalida) ectosymbiont on giant water bugs, Belostoma spp. (Hemiptera, Belostomatidae) from southern Brazil. Revista Brasileira de Zoologia 22 (1): 107-118.

Амato, J.F.R.; S.B. Амato \& S.A. Seixas. 2005. Temnocephala lutzi Monticelli (Platyhelminthes, Temnocephalida) ectosymbiont on two species of Trichodactylus Latreille (Crustacea, Decapoda, Trichodactylidae) from southern Brazil. Revista Brasileira de Zoologia 22 (4): 1085-1094.

Aмato, J.F.R.; S.B. Амato \& S.A. Seixas. 2006. A new species of Temnocephala Blanchard (Platyhelminthes, Temnocephalida) ectosymbiont on Trichodactylus fluviatilis Latreille (Crustacea,
Decapoda, Trichodactylidae) from southern Brazil. Revista Brasileira de Zoologia 23 (3): 796-806.

Amato, J.F.R.; S.A. Seixas \& S.B. Amato. 2007. A new species of Temnocephala Blanchard (Platyhelminthes, Temnocephalida) ectosymbiont on creeping water bugs, Cryphocricos granulosus, De Carlo (Hemiptera, Naucoridae) from southern Brazil. Revista Brasileira de Zoologia 24 (4): 1043-1051.

Damborenea, M.C. 1994. Temnocefalos neotropicales: Temnocephala kingsleyae sp. nov. y T. lutzi Monticelli, 1913 (Platyhelminthes, Temnocephalidea) comensales de crustáceos de Brasil. Iheringia, Série Zoologia, 77: 99-105.

Damborenea, M.C. \& F. Brusa. 2008. A new species of Temnocephala (Platyhelminthes, Temnocephalida) commensal of Pomella megastoma (Mollusca, Ampullariidae) from Misiones, Argentina. Revista Mexicana de Biodiversidad 79: 1S-7S.

Damborenea, M.C. \& L.R.G. Cannon. 2001. On neotropical Temnocephala (Platyhelminthes). Journal of Natural History 35: 1103-1118.

Haswell, W.A. 1893. A monograph of the Temnocephaleae, p. 93-152. In: J.J. Fletcher (Ed.). Proceedings of the Society of New South Wales: The Macleay Memorial Volume.

PonCe de León, R. 1979. Espécies americanas de Temnocephalidea Benham (Platyhelmintha), I. Descripcion de Temnocephala rochensis $\mathrm{n}$. sp. de la camara paleal de Pomacea canaliculata (Lamarck). Revista de Biologia del Uruguay 7 (1): 39-48.

Ponce De León, R. 1989. Description of Temnocephala haswelli n. sp. (Platyhelminthes) from the mantle cavity of Pomacea canaliculata (Lamarck). Journal of Parasitology 75 (4): 524526.

Seixas, S.A.; J.F.R. Amato \& S.B. Amato. (2010a). Redescription of Temnocephala iheringi (Platyhelminthes: Temnocephalida) based on specimens from Pomacea canaliculata (Mollusca: Ampullariidae) of the state of Rio Grande do Sul, Brazil: the possible type host and type locality. Zoologia 27 (2): 245-257.

Seixas, S.A.; J.F.R. Амato \& S.B. Амato. (2010b). First report of Temnocephala haswelli (Platyhelminthes: Temnocephalida) in Pomacea canaliculata (Mollusca: Ampullariidae) from Brazil: description update based on specimens from the state of Rio Grande do Sul, Brazil. Zoologia 27 (3): 455-464.

Volonterio, O. 2007. A new species of Temnocephala (Platyhelminthes, Temnocephalida) and a description of T. axenos from Uruguay. Journal of Natural History 41 (21-24): 12451257.

Submitted: 23.XI.2009; Accepted: 27.VIII.2010.

Editorial responsibility: Marcus V. Domingues 